\title{
Néhány nyugat-dunántúli talaj könnyen oldható mikroelem- tartalmának hosszú idő alatt bekövetkezett változása
}

\author{
SZÜCS MIHÁLY és SZÜCS MIHÁLYNÉ
}

Nyugat-Magyarországi Egyetem, Mezőgazdaságtudományi Kar, Mosonmagyaróvár, Talajtani és Vízgazdálkodási Tanszék

Az esszenciális mikroelemek fontos szerepet játszanak a talaj termékenységében. Mennyiségükről - a hazánkban 1978 óta egységes módszerekkel folyó talajvizsgálatok révén - egyre több információt szerzünk. Hosszabb távú változásuk elörejelzéséhez azonban még nem rendelkezünk elegendő adattal.

A mikroelemekhez a periódusos rendszer különböző csoportjaiba tartozó fémek $(\mathrm{Cu}, \mathrm{Mn}, \mathrm{Mo}, \mathrm{Zn})$ és félfém (B) is tartozik, tulajdonságaik ezért nagyon különbözőek.

A talaj mikroelem tápanyag-szolgáltató képessége megítélésének alapjául szolgáló könnyen oldható mikroelem-tartalom elemenként általában az összes mennyiség $1 \%$-át teszi ki, bór és molibdén esetében elérheti a 10-15\%-ot (SZABÓ et al., 1987).

A talaj mikroelem-szolgáltató képessége a könnyen oldható mikroelem-tartalmon kívül leginkább a pH-viszonyoktól függ. A B-, Cu-, Mn- és Zn-ellátottság általában negatív, a Mo-ellátottság pedig pozitív kapcsolatot mutat a $\mathrm{pH}$-értékkel (SZABÓ et al., 1987; SzÜCSNÉ, 1989). SILLANPÄÄ (1982) magyar vonatkozású felmérést is tartalmazó vizsgálata szerint a növények Mo-tartalma pozitív korrelációt mutatott a talaj pH-jával, a talaj könnyen oldható Mo-tartalma viszont ezt nem követte, a legnagyobb értékeket pH 6-7 között érte el. Más mikroelemek esetében is megfigyelték, hogy könnyen oldható mennyiségük szélsőséges pH-értékek esetében erősen visszaesik (AUBERT \& PINTA, 1977). Más tulajdonságok szélsőséges értékei is eredményezhetnek csökkent oldhatóságot. KABATA-PENDIAS és PENDIAS (1992) vizsgálatai szerint bór, réz és mangán mikroelemek esetében a szélsőséges szervesanyag-tartalom, bór estében még a homok fizikai féleség, molibdénnél a sok vas- és alumínium-oxid, cinknél pedig a szabad $\mathrm{CaCO}_{3}$ is lehet a hiány oka.

A talajok mikroelem-ellátottságának vagy mikroelem-tartalmának a talajtulajdonságokkal való összefüggését általában azonos időben vett minták vizs- 
gálata útján ellenőrzik. Kevés adattal rendelkezünk abban a vonatkozásban, hogy a talajok könnyen oldható mikroelem-tartalma egy adott helyen miként változik az idővel, milyen szerepe van a különböző körülmények között eltelt időnek a mikroelem-tartalom kialakulásában.

GYÖRI (1984) mikroelemmérleg számításai valamennyi esszenciális mikroelem vonatkozásában határozottan negatív értéket mutatnak. Az alkalmazott számítás azonban elsősorban csak országos anyagforgalmi becslések végzésére alkalmas. Helyi mérlegek számítása esetén például figyelmen kívül kell hagynunk az egyébként jelentős tételt képező eróziós veszteséget, ha a felszín közelébe jutó laza kőzet oldható mikroelem-tartalma nem sokkal kisebb, mint a leerodálódott feltalajé volt. Nem tartalmaz a mérlegszámítási módszer adatokat az összes és az oldható forma közötti átmenet becslésére, pedig a mobilitás-immobilitás egyensúlya tartamhatások esetében fontos szerepet játszhat.

Mütrágyázási tartamkísérletekben (DEBRECZENI \& DEBRECZENINÉ, 1994) 20 év alatt jelentős változást csak a savanyú talajok oldható bórtartalmában találtak. A tartamkísérletben a mütrágyázott és a kontrollparcellák adatait hasonlították össze a kísérlet 20. évében vett minták alapján. A környezeti tényezők a kontrollparcellára is hatnak, tehát a kísérlet előtti állapottal való összehasonlítás ilyen módon nem lehetséges.

Jelen munkánkban az 1970-es évek elején végzett talajvizsgálatok légszáraz állapotban tárolt mintáinak felhasználásával, a vizsgált területek 25-27 év utáni újramintázásával és a minták azonos időben történő vizsgálatával mértük fel üzemi területeken a mikroelem-tartalom változásokat. Arra a kérdésre kerestük a választ, hogy a barna erdőtalajokkal borított területeken mely esszenciális mikroelemek oldható mennyiségének változását határozza meg döntően a növény általi felvétel és a kimosódás, valamint milyen esetekben múlja ezt felül a mobilizációs-immobilizációs folyamatok természetes és antropogén hatásokra eltolódó egyensúlya. Ezeknek az ismereteknek a birtokában tudnánk megfontolni, hogy milyen esetekben lehet célravezető a mikroelemhiányok közvetlen pótlása talajon vagy levélen keresztül és mikor kell inkább a környezeti tényezők megváltoztatására törekednünk.

\section{Anyag és módszer}

A talajok KCl-EDTA-oldható mikroelem-tartalma hosszú távú változásainak méréséhez az 1971-1973. évek között a Nyugat-Magyarországi-peremvidéken és a Kisalföldön gyüjtött és légszáraz állapotban tárolt mintákat használtuk fel. A mintavételi helyeket (1. ábra) 25-27 év elteltével, navigációs GPS segítségével megkeresve újra megmintáztuk oly módon, hogy három évre elosztva, évente 50 mintavételi nyomvonalat kerestünk fel. 


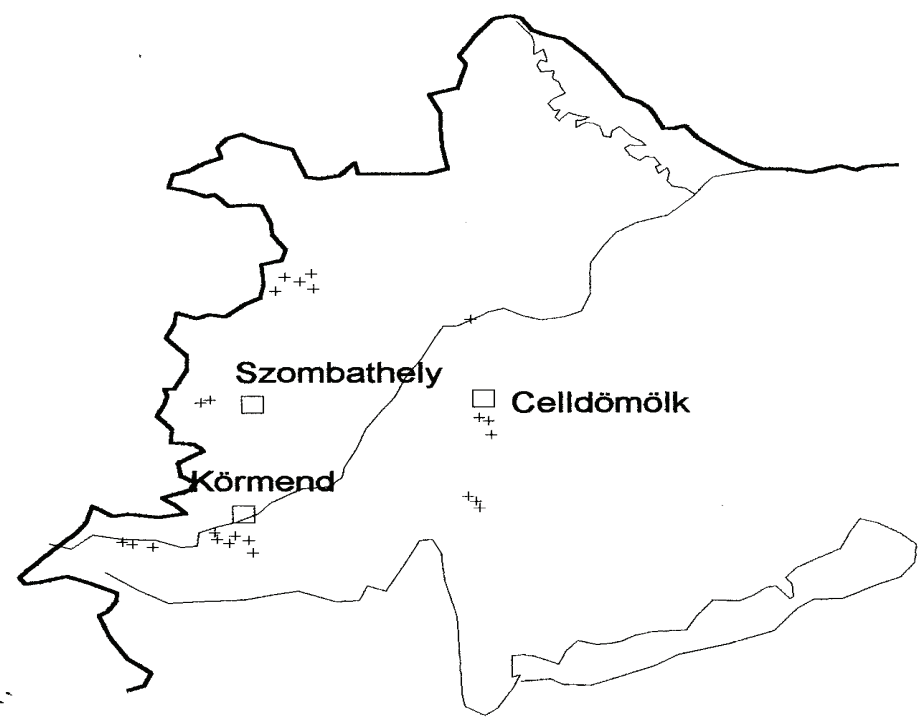

1. ábra

A mintavételi helyek

$A+$ jelek a mintavételezéssel érintett települések központját jelölik

1998-ban a Kisalföldön, a Marcal-medencében, a Kemenesalja kistájhoz tartozó települések (Dabronc, Hetyefö, Zalaerdőd, Izsákfa, Boba és Nemeskocs) határában végeztünk mintavételezést. A vizsgált területet föképpen homok és homokos vályog mechanikai összetételü agyagbemosódásos barna erdőtalajok borítják. Kevés esetben a mintavételi nyomvonalban karbonátos talajfoltok is előfordultak.

1999-ben a Nyugat-Magyarországi-peremvidék északi felében, az Alpokalján (Torony és Dozmat), a Sopron-Vasi-síkságon (Sopronhorpács, Und, Zsira, Egyházasfalu, Völcsej) és Felső-Kemenesháton (Pápoc) vettünk mintát. Az uralkodó talajtípus az agyagbemosódásos barna erdőtalaj és a Ramann-féle barna erdőtalaj volt, de előfordultak öntéstalajok is, amelyek a Rába hatásterületén mindig savanyú kémhatásúak. Sopronhorpács környékén több karbonátos talajfoltot is találtunk.

2000-ben a Nyugat-Magyarországi-peremvidék déli felében, Alsó-Kemeneshát (Nádasd, Katafa, Halogy, Hegyhátsál, Hegyháthodász, Daraboshegy) és a Vasi-Hegyhát (Rábagyarmat, Csörötnek és Magyarlak) külterületeiről gyüjtöttünk mintákat. Itt kivétel nélkül karbonátmentes mintákkal találkoztunk, amelyek pangóvizes barna erdőtalajokból, agyagbemosódásos barna erdőtalajokból és a Rába vonzáskörzetében savanyú öntéstalajokból származtak. 
Az eredeti és az ugyanott újra begyüjtött mintákat mindhárom évben, azonos vizsgálati napon $\mathrm{KCl}$-EDTA-oldható mikroelem-tartalomra megvizsgáltattuk. A vizsgálatokat a Vas Megyei Növényvédelmi és Agrokémiai Állomás végezte.

\section{Kísérleti eredmények és értékelésük}

Az 1998., 1999. és 2000. években elvégzett általános talajvizsgálatok eredményeit az 1. táblázat, a KCl-EDTA oldható mikroelem-vizsgálatok eredmé-

1. táblázat

A talajok laboratóriumi vizsgálati adatai, $\mathbf{n}=\mathbf{5 0}$

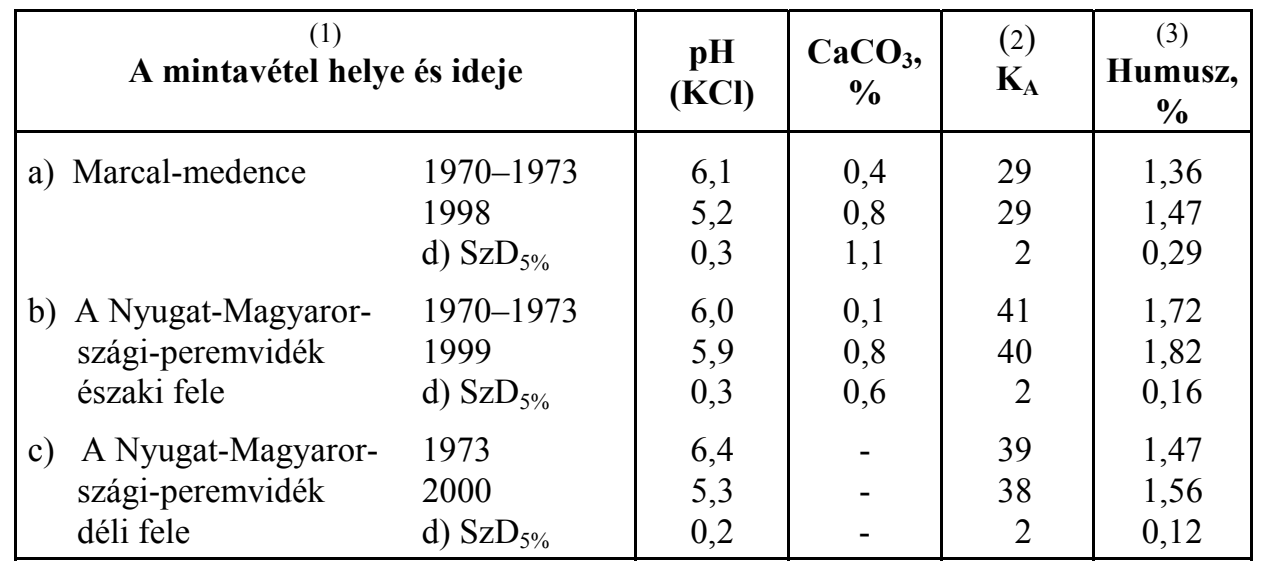

ményeit a 2. táblázat tartalmazza. A középértékek összehasonlítására $\mathrm{SzD}_{5 \%}$-értékeket számítottunk SVÁB (1981) leírása szerint.

Az 1. táblázat adatai alapján megállapítható, hogy az 1970-es évek elején történt mintavétel óta jelentős és szignifikáns csökkenés következett be a talajok pH-értékében. Az expozíciós idő magába foglalja a 70-es és 80 -as évek viszonylag nagyobb mütrágya-felhasználású időszakát, ami szerepet játszhatott a talajok pH-csökkenésében. A pH-csökkenés a Sopronhorpács és Pápoc környékén vett minták vizsgálata alapján nem bizonyítható, mert ezen a területen az 1999-ben vett átlagmintákba több karbonátos folt anyaga került bele, mint az első mintavétel idején. Ennek valószínüleg az az oka, hogy a vidékre jellemző lösz jellegű alapkőzet az erózió miatt több helyen a felszín közelébe került. A legkisebb kötöttségi számot és szervesanyag-tartalmat a Marcal-medencéből származó mintákban mértük.

A 2. táblázat adatai szerint a talajok könnyen oldható bórtartalma mindhárom mintavételi körzetben szignifikánsan csökkent. Hasonló eredményre ju- 
AGROKÉMIA ÉS TALAJTAN Tom. 50. (2001) No. 3-4.

\section{2. táblázat}

A KCl-EDTA-oldható talaj mikroelem-vizsgálat eredményei, $\mathbf{n}=50$

\begin{tabular}{|c|c|c|c|c|c|c|c|}
\hline \multirow{2}{*}{\multicolumn{3}{|c|}{ A mintavétel helye és ideje }} & B & $\mathrm{Cu}$ & Mn & Zn & Mo \\
\hline & & & \multicolumn{5}{|c|}{$\mathrm{mg} / \mathrm{kg}$} \\
\hline \multirow[t]{3}{*}{ a) } & Marcal- medence & $1970-1973$ & 0,34 & 2,77 & 140 & 1,80 & 0,065 \\
\hline & & 1998 & 0,12 & 1,98 & 155 & 1,61 & 0,094 \\
\hline & & d) $\mathrm{SzD}_{5 \%}$ & 0,06 & 0,51 & 25 & 0,44 & 0,020 \\
\hline \multirow[t]{3}{*}{ b) } & A Nyugat-Magyar- & $1970-1973$ & 0,45 & 4,90 & 181 & 3,60 & 0,040 \\
\hline & országi-peremvidék & 1999 & 0,26 & 4,55 & 220 & 2,27 & 0,074 \\
\hline & északi fele & d) $\mathrm{SzD}_{5 \%}$ & 0,1 & 0,63 & 38 & 0,91 & 0,008 \\
\hline \multirow[t]{3}{*}{ c) } & A Nyugat-Magyar- & 1973 & 0,37 & 2,76 & 148 & 1,74 & 0,056 \\
\hline & országi-peremvidék & 2000 & 0,18 & 2,50 & 179 & 2,54 & 0,090 \\
\hline & déli fele & d) $\mathrm{SzD}_{5 \%}$ & 0,08 & 0,59 & 26 & 0,52 & 0,018 \\
\hline
\end{tabular}

tunk a magyarországi mütrágyázási tartamkísérletek (DEBRECZENI \& DEBRECZENINÉ, 1994) eredményeinek elemzése alapján is. Ott a hat savanyú talajú vizsgálati helyből öt esetben tapasztaltak szignifikáns bórtartalom-csökkenést 20 évi mütrágyázás hatására. A 6. vizsgálati helyen a kiindulási érték nagyon kicsi, a mérési határ közeli érték volt, valószínűleg ezért nem volt detektálható a változás. Más szerzők is tapasztaltak korábban mütrágyázás hatására bekövetkező oldható bórtartalom-csökkenést. NIKISKINA (1963) szántóföldi tartamkísérletek, ARONSSON (1983) pedig mütrágyázott fenyőültetvények esetében figyelt meg hasonló hatást. A jelenség oka a mütrágyák talajsavanyító és termésnövelő hatására egyaránt visszavezethető. Savanyú körülmények között az amorf oxidok bórmegkötése csökken (HATCHER et al., 1967; METWALLY et al., 1974.), ami lehetővé teszi a fokozott kimosódást és a növények által történő felvételt. MURAWSZKA (1993) 12 éven át tenyészedényekben végzett tartamkísérletének adatai azt mutatják, hogy a mütrágyázás hatására a kimosódás lehetősége nélkül is csökken az oldható B-tartalom. Ennek oka az lehet, hogy a fokozott felvétel hatására bekövetkező csökkenést a mállási folyamatok a nehezen bomló ásványokból (döntően turmalin), amelyekben az összes bór jelentős része található (SZABÓ et al., 1987), nem tudják megfelelő sebességgel pótolni. A jelenséget feleslegben lévő könnyen oldható bór biológiai úton történő eltávolítására is ajánlják (BANUELOS et al., 1995).

$\mathrm{Az}$ oldható $\mathrm{Cu}$-tartalomban szignifikáns csökkenést csak a homok mechanikai összetételü marcal-medencei minták vizsgálata esetében találtunk (2. táblázat). A pH csökkenésével csökken a réz $\mathrm{CuOH}^{+}$irányába történő hidrolízise, ami szorpciócsökkenést eredményez (MISRA \& TIWARI, 1966). Ez azonban nem vezet nagymértékủ kimosódáshoz (KORTE et al, 1976.). Liziméteres vizsgálatok során is inkább csak szuszpenzióhoz kötötten találták meg, mint valódi oldatban 
(ARZSANOVA \& ElPAT’EVSZKIJ, 1979). Ezért GYŐRI (1984) kimosódási veszteséggel nem is számol. Szabadföldi tartamkísérletekben (DEBRECZENI \& DEBRECZENINÉ, 1994) és kimosódást kizáró tenyészedény-kísérletekben (MURAWSZKA, 1993) az esetek egy részében mégis megfigyelhető az oldható réztartalom csökkenése, ami kis kolloidtartalmú talajokban, a növények fokozott felvételi ütemét követni nem képes feltáródás következménye lehet.

A növények Mn-felvétele és a talaj pH-ja között megfigyelt fordított irányú összefüggést (AUBERT \& PINTA, 1977) olyan mértékben jellemzőnek tartják, hogy a fák évgyürüinek Mn-koncentrációját régi idők talaj $\mathrm{pH}$-változásainak követésére javasolják használni (GUYETTE et al., 1992). A talaj oldható Mntartalmának alakulásában a pH hatás korlátozottabban érvényesül (SILLANPÄÄ, 1982), ezenkívül a redukciónak is fontos szerepe van, mert csak a kétvegyértékü forma vízoldható (SZABÓ et al., 1987). Ha GYÖRI (1984) adatait az eróziós veszteség figyelmen kívül hagyásával újraszámoljuk, mangán esetében egyensúlyi mérleghez jutunk.

Vizsgálataink szerint az oldható Mn-artalom (2. táblázat) a homok mechanikai összetételü - ezért jobban levegőzött - marcal-medencei minták kivételével még a foltosan karbonátos mintavételi területen (Sopronhorpács) is igazolhatóan nött. Ez azt bizonyítja, hogy Mn-tartamhatások vizsgálata esetében a redukció feltételeinek szerepe fontosabb, mint a kémhatásváltozás. Ezért a tartamkísérletek, kivitelezési technikájuk függvényében egymásnak látszólag ellentmondó oldható Mn-tartalom-változás eredményeket adhatnak. A magyarországi mütrágyázási tartamkísérletekben (DEBRECZENI \& DEBRECZENINÉ, 1994) nem tapasztaltak az oldható mangán mennyiségében különbséget a kezelések között. Ennek oka, hogy a környezeti hatások a kontrollparcellára is hatnak. A kezelésekben alkalmazott műtrágyázás csak az egyik oka a talajok kémhatásváltozásának, a redukciós viszonyokat pedig még kevésbé befolyásolja. MURAWSZKA (1993) tenyészedény-tartamkísérletében minden kezelésben jelentős oldható Mn-tartalom-csökkenést figyelt meg. A szerző kevés részletet közöl a kísérlet körülményeiröl, de feltételezhetö, hogy az évenkénti mütrágyaadagolások miatt rendszeresen ki kellett szednie a talajt az edényekből, majd azt újra visszatöltenie, ami fokozott levegöztetést okozott, csökkentve ezzel a redukciót. Vizsgálataink alapján megállapítható, hogy a feltáródási folyamatok, a $\mathrm{pH}$ és a redoxiviszonyok egymást erősítő változásai esetén képesek a növény által történő felvételt és a kimosódási veszteséget meghaladó mértékủ oldható Mn-tartalmi változásokat elöidézni.

Az oldható Zn-tartalom vizsgálataink (2. táblázat) szerint a karbonátmentes mintavételi körzetben szignifikáns növekedés, a mészfoltos területen pedig szignifikáns csökkenés volt regisztrálható. A jelentős pH-csökkenés ellenére sem volt bizonyítható változás a marcal-medencei területen, ahol helyenként mészfoltok kerültek a mintavételi nyomvonalba. Adataink GYÖRI (1984) nega- 
tív Zn-mérlegre vonatkozó véleményét nem támasztják alá. Úgy tünik, hogy a savasság növekedésével jelentkező Zn-oldhatóság növekedése (SILLANPÄÄ, 1982; SzABÓ et al., 1987) vagy a szabad $\mathrm{CaCO}_{3}$ hatására bekövetkező oldhatóság-csökkenés (KALBASI et al., 1978; KABATA-PBNDIAS \& PENDIAS, 1992) nagyobb változásokat okoz, mint a növény által történő felvétel és a kimosódás. Ezzel magyarázható, hogy az egységes módszerekkel beállított országos mütrágyázási tartamkísérletek mütrágyázott parcelláinak talajában (DEBRECZENI \& DEBRECZENINÉ, 1994) nem találtak lényeges változást a kontrollhoz képest.

3. táblázat

Az oldható Fe- és Al-tartalom változása, $n=50$

\begin{tabular}{|ll|r|r|}
\hline \multirow{2}{*}{ A mintavétel helye és ideje } & Fe & Al \\
\cline { 2 - 4 } a) Marcal- medence & $1970-1973$ & 123 & $\mathbf{2}$ \\
& 1998 & 136 & 62 \\
& d) $\mathrm{SzD}_{5 \%}$ & 24 & 98 \\
b) A Nyugat-Magyar- & $1970-1973$ & 154 & 13 \\
országi-peremvidék & 1999 & 191 & 95 \\
északi fele & d) $\mathrm{SzD}_{5 \%}$ & 36 & 95 \\
c) A Nyugat-Magyar- & 1973 & 126 & 63 \\
országi-peremvidék & 2000 & 189 & 84 \\
déli fele & d) $\mathrm{SzD}_{5 \%}$ & 26 & 10 \\
\hline
\end{tabular}

Valamennyi vizsgálati helyen az oldható Mo-tartalom szignifikáns növekedését mértük (2. táblázat). Ez egyezik több szerző (SZABÓ et al., 1987; KABATA-PENDIAS \& PENDIAS, 1992) megfigyelésével, amely szerint savanyú talajokban a molibdén a vas-, alumínium- és mangán-oxidokhoz kötődve felhalmozódik. A 2. és 3. táblázatokban megtalálható adatok szerint a redukcióra hajlamosabb talajokban inkább a mangán- és a vas-oxidok, az erősebb savanyodást szenvedett talajokban pedig az alumínium-oxid jelenlétére utaló mérési eredmények mutattak szignifikáns növekedést. A növekedés mértékétől függetlenül az oldható Mo-tartalom növekedések mértéke szignifikáns összefüggést mutatott az oxidok mennyiségére utaló mangán, vas és alumínium mérési eredményeivel (4. táblázat). A pH csökkenésével a Mo-szorpció erösödik (BARROW, 1970; HAYNES, 1983), ezért a kimutatott felhalmozódás nem jelent azonos arányú ellátottság javulást is egyben. Régóta ismert (MÜLLER, 1964), hogy az oldható Mo-tartalmi adatokat legalább a pH-érték figyelembe vételével korrigálni kell az ellátottság megítéléséhez. 


\section{4. táblázat}

A talaj oldható Mo-tartalma változásának összefüggése a Mn-, a Fe- és az Altartalom változásával, $n=48$

\begin{tabular}{|l|c|c|c|}
\hline \multicolumn{1}{|c|}{ A vizsgálat helye } & \multicolumn{2}{|c|}{$(2)$ Korrelációs koefficens, $\mathbf{~}$} \\
\cline { 2 - 4 } & $\mathbf{M n}$ & $\mathbf{F e}$ & $\mathbf{A l}$ \\
\hline a) Marcal- medence & $0,48 * * *$ & $0,58 * * *$ & $0,36 * *$ \\
$\begin{array}{l}\text { b) A Nyugat-Magyarországi-perem- } \\
\text { vidék északi fele }\end{array}$ & $0,69 * * *$ & $0,62 * * *$ & $0,68 * * *$ \\
$\begin{array}{l}\text { c) A Nyugat-Magyarországi-perem- } \\
\text { vidék déli fele }\end{array}$ & $0,62 * * *$ & $0,49 * * *$ & $0,46 * *$ \\
\hline
\end{tabular}

Megjegyzés: Az összefüggés ** $1 \% * * * 0,1 \%$ hibaszinten szignifikáns

Mindenesetre a GYŐRI (1984) által feltételezett erősen negatív mérleg ezeken a savanyú talajokon nem értelmezhető.

\section{Összefoglalás}

Légszáraz állapotban tárolt talajminták és mintavételi helyeinek 25-27 év elteltével végzett ismételt mintavételezése után vizsgáltuk a Marcal-medencében és a Nyugat-Magyarországi-peremvidéken a KCl-EDTA-oldható mikroelem-tartalom változását üzemi viszonyok között. A jellemzett időtartam magában foglalja azt az időszakot, amikor viszonylag nagyobb műtrágyaadagokat alkalmaztak az üzemek. A vizsgálat a természetes és a humán eredetủ környezeti tényezők együttes, hosszú távú hatása törvényszerüségeinek tanulmányozására irányult.

A vizsgált, döntően barna erdőtalajok által borított régióban a talajok kémhatása az expozíciós idő alatt általában 1 pH-értékkel csökkent, a szervesanyagtartalom viszont nem változott.

$\mathrm{Az}$ oldható B- és Cu-tartalomban csökkenés, a Mn- és Mo-tartalomban növekedés, a Zn-tartalomban pedig csökkenés és növekedés egyaránt tapasztalható volt.

Az oldható B-tartalom valamennyi vizsgált helyen, az oldható Cu-tartalom a homok fizikai féleségü talajokban csökkent szignifikánsan. Ezekben az esetekben feltételezhető, hogy a növény általi felvétel és a kimosódás útján a rendszerből kikerülő mikroelemek pótlását a feltáródás nem képes megfelelő sebességgel pótolni.

$\mathrm{Az}$ oldható Mn esetében a redukció és a $\mathrm{pH}$-csökkenés együttes oldó hatása, a Mo esetében pedig a Mn-, Fe- és Al-oxidokon történő megkötődés hoz létre veszteségeket meghaladó változást. 
Az oldható Zn mennyisége a karbonátmentes savanyú talajon a pH-csökkenés hatására szignifikánsan nőtt, a meszes foltokat tartalmazó halmazban pedig csökkent. Megállapítható tehát, hogy a pH-változás hatása nagyobb, mint a felvételi és kimosódási veszteségeké.

Jelen kutatást az OTKA támogatásával végeztük a T025091 kutatási pályázat keretében.

\section{Irodalom}

ARONSSON, A., 1983. Growth disturbances caused by boron deficiency in some fertilized pine and spruce stands on mineral soils. Communicationes Instituti Forestalis Fenniae. 116. 116-122.

ARZSANOVA, V. Sz. \& ElPAT'EVSZKIJ, P. V., 1979. Migracija mikroélementov v burüh gornolesznüh pocsvah. Pocsvovedenie. 11. 51-60.

Aubert, H. \& PinTA, M., 1977. Trace Elements in Soils. Elsevier. AmsterdamOxford-New York.

BANUELOS, G. S. et al., 1995. Bioextraction of soil boron by tall fescue. Ecotoxicology and Environmental Safety. 31. (2) 110-116.

BARROW, N. J., 1970. Comparison of the adsorption of molybdate, sulfate and phosphate by soils. Soil Sci. 109. 282-288.

DebreCZENI B. \& DebreCZENI B-NÉ (Szerk.), 1994. Trágyázási kutatások 1960-1990. Akadémiai Kiadó. Budapest.

Guyette, R. P., Henderson, G. S. \& Cutter, B. E., 1992. Reconstructing soil pH from manganese concentrations in tree-rings. Forest-Sci. 38. 727--737.

GYÖRI ., 1984. A talaj termékenysége. Mezőgazdasági Kiadó. Budapest.

HATChER, J. T., BOWER, C. A. \& ClARK, M., 1967. Adsorption of boron by soils as influenced by hydroxy aluminum and surface area. Soil Sci. 104. 422-426.

HAYNES, R. J., 1983. Effect of lime and phosphate applications on the adsorption of phosphate, sulfate, and molybdate by a Spodosol. Soil Sci. 135. 221-227.

Kabata-Pendias, A. \& Pendias, H., 1992. Trace Elements in Soils and Plants. $2^{\text {nd }}$ ed. CRC Press, Ltd. Boca Raton. Fl. USA

Kalbasi, M., RaCZ, G. J. \& Rudgers-Loewen, L. A., 1978. Mechanism of zinc adsorption by iron and aluminum oxides. Soil Sci. 125. 146-150.

KORTE, N. E. et al., 1976. Trace element movement in soils: Influence of soil physical and chemical properties. Soil Sci. 122. 350-359.

Metwally, A. I., El-Damaty, A. H. \& YousRY, M., 1974. Amorf oxidok bórmegkötése. Agrokémia és Talajtan. 23. 59-70.

MISRA, S. G. \& TIWARI, R. C., 1966. Retention and release of copper and zinc by some Indian soils. Soil Sci. 101. 465-471.

MURAWSZKA, B., 1993. Vlijanie mnogoletnego vneszenija mineral'nüh udobrenij na szoderzsanie miroélementov v pocsvah. Pocsvovedenie. 11. 78-80.

MÜLLER, K. H., 1964. Molybdändüngungsversuche zu Luzerne. Bericht über Versuchs - und Untersuchungsergebnisse der fahre 1960-1962. Jena. 467-470. 
NiKISKINA, P. I., 1963. Vlijanie dlitel'nogo vneszenija organicseszkih i mineral'nüh udobrenij na podvizsnoszt' mikroélementov v pocsve. Pocsvovedenie. 9. 13-20.

SILlANPÄ̈̈, M., 1982. Micronutrients and the Nutrient Status of Soils: A Global Study. FAO Soils Bulletin No. 48. FAO. Rome.

SvÁB J., 1981. Biometriai módszerek a kutatásban. Mezőgazdasági Kiadó. Budapest.

SzABÓ S. A. et al., 1987. Mikroelemek a mezőgazdaságban I. (Esszenciális mikroelemek). Mezőgazdasági Kiadó. Budapest.

SzÜCS M-NÉ, 1989. A talajtulajdonságok és a könnyen oldódó mikroelem-tartalom összefüggései barna erdőtalajokban. Acta Ovariensis. XXXI. (4) 66-77.

Érkezett: 2001. április 18. 


\title{
Long-term Changes in the Soluble Micronutrient Content of Some West Hungarian Soils
}

\author{
M. SZÜCS and L. SZÜCS \\ Department of Soil Science and Water Management, University of West Hungary, \\ Mosonmagyaróvár (Hungary)
}

\begin{abstract}
Summary
Comparative studies were made on the KCl-EDTA-soluble micronutrient contents of soil samples taken from farm fields in the Western part of Hungary and stored in the air-dry state, and on samples taken at the same sites after an interval of 25-27 years, in the course of which relatively high rates of mineral fertilizers were applied on the farms for a long period. The investigation was carried out to study the long-term joint influence of environmental factors of natural and anthropogenic origin on the readily soluble micro-nutrient content of the soils.

The $\mathrm{pH}$ of the brown forest soils investigated decreased by one unit during the experimental period, whereas the organic matter content remained unchanged.

The readily soluble $\mathrm{B}$ and $\mathrm{Cu}$ contents of the soils decreased, and the $\mathrm{Mn}$ and $\mathrm{Mo}$ contents increased over time, while the $\mathrm{Zn}$ content increased in some areas and decreased in others.

The decrease in the readily soluble B content was significant at all the sampling sites, while that of the $\mathrm{Cu}$ content was only significant on sandy-textured soils. It was concluded that the natural mobilization processes of the soils were unable to replenish the soluble forms of these elements lost from the system due to plant uptake and leaching.

The decrease in the redox potential and soil $\mathrm{pH}$ increased the amount of soluble $\mathrm{Mn}$ over time, to an extent exceeding the losses, except on well-aerated sandy soils. The content of soluble Mo was similarly increased in all soils due to its adsorption on $\mathrm{Mn}$, Fe and Al oxides.

The amount of soluble $\mathrm{Zn}$ increased in non-calcareous acidic soils and decreased in soils with calcareous patches. This means that $\mathrm{pH}$ had a greater influence on the soluble Zn content than the losses due to uptake and leaching.
\end{abstract}

Table 1. Data of laboratory soil analyses, $\mathrm{n}=50$. (1) Site and time of sampling. a) Marcal Basin, b) Northern part of the West Hungarian Borderland, c) Southern part of the West Hungarian Borderland, d) $\mathrm{LSD}_{5 \%}$. (2) Upper limit of plasticity. (3) Humus $\%$.

Table 2. Results of the KCl-EDTA-soluble soil micronutrient analysis, $\mathrm{n}=50$. (1) Site and time of sampling. a) Marcal Basin, b) Northern part of the West Hungarian Borderland, c) Southern part of the West Hungarian Borderland, d) $\operatorname{LSD}_{5 \%}$.

Table 3. Changes in the soluble Fe and Al contents of the soils, $\mathrm{n}=50$. (1) Site and time of sampling. a) Marcal Basin, b) Northern part of the West Hungarian Borderland, c) Southern part of the West Hungarian Borderland, d) $\operatorname{LSD}_{5 \%}$. 
Table 4. Correlation between changes in soluble Mo content and changes in the soluble $\mathrm{Mn}, \mathrm{Fe}$ and $\mathrm{Al}$ contents of the soils, $\mathrm{n}=48$. (1) Site of sampling. a) Marcal Basin, b) Northern part of the West Hungarian Borderland, c) Southern part of the West Hungarian Borderland. (2) Coefficient of correlation, r. Remarks: ** significant at the $1 \%$ probability level, $* * *$ significant at the $0.1 \%$ probability level.

Fig. 1. Sampling sites. The + symbols indicate the centres of the settlements where the soil samples were taken. 